\title{
Ensaio: um outro modo de dizer amigo
}

\author{
JESSICA DI CHIARA *
}

RESUMO Parece fundamental ou mesmo incontornável recorrer aos Ensaios, de Michel de Montaigne, quando se trata de pensar o ensaio como um gênero específico. Publicado a partir de 1580 e tendo grande repercussão à época, com esse livro Montaigne inaugura simultaneamente um gênero e um modo de pensar. Um dos modos de ler a singularidade do ensaio enquanto forma pode se dar a partir da chave da amizade - particularmente daquela vivida por Michel de Montaigne e Étienne de La Boétie. A história dessa amizade é amplamente conhecida e tematizada na história da filosofia e, nesse contexto, o ensaio " $\mathrm{Da}$ amizade” é testemunho emblemático dessa relação. Fazendo da relação particular de amizade com La Boétie um paradigma de amizade, nesse ensaio o absoluto funda-se num caso particular, o que faz com que a verdade passe a ter relação de fundamento não com o método da prova, mas sim com o testemunho de uma singularidade. É possível projetar esse procedimento de fundamentação (particular e não geral) para o modo próprio de construção de cada texto dos Ensaios, transformando a atenção à particularidade do "absoluto" fundado cada vez numa característica do gênero na história da filosofia. Nesse artigo, trata-se de pensar o ensaio enquanto um gênero radicalmente filosófico a partir da perspectiva da amizade como enunciada em Montaigne.

PALAVRAS-ChAVE Ensaio; amizade; Michel de Montaigne; Theodor Adorno; Giorgio Agambem.

* Mestre em Filosofia pela Universidade Federal Fluminense 
"Porque era ele, porque era eu"

Michel de Montaigne

"Quando na comunicação dos pensamentos alternamo-nos entre absoluto entendimento e absoluto não-entendimento, isso já pode ser chamado uma amizade filosófica"

Novalis, "Pólen”, fragmento 20

\section{MONTAIGNE: LES AUTRES FORMENT L'HOMME; JE LE RECITE}

Parece fundamental ou mesmo incontornável, seja na literatura, seja na filosofia, recorrer aos Ensaios, de Michel de Montaigne, quando se trata de pensar o ensaio como um gênero específico. Publicado em três volumes entre 1580 e 1588 e tendo grande repercussão à época, ${ }^{1}$ com os Ensaios Montaigne inaugura, de fato, simultaneamente um gênero e um modo de pensar. Reunindo em um só livro assuntos e textos diversos (desde temas clássicos a assuntos corriqueiros e esdrúxulos até questões polêmicas), ${ }^{2}$ os Ensaios são um livro formal e intrinsecamente plural - e essa é uma de suas principais características e novidade. A outra - mais radical - é a afirmação da singularidade daquele que escreve. Colocando, a cada ensaio, assuntos diversos em relação de vizinhança como quem soubesse de tudo e ao mesmo tempo não se especializasse em nada, Montaigne não pretende, com esse gesto, tudo conhecer. Como afirma Eric Auerbach, ele permanece "leigo mesmo onde parece compreender algo do assunto" e é difícil acreditar que ele quisesse se aprofundar em alguma das "matérias de que

1 Mostras disso são as constantes reedições dos Ensaios em poucos anos. Segundo Edson Querubini: “os Ensaios de Montaigne tiveram várias edições durante a vida e logo após a morte do autor: a primeira, de 1580, publicada em Bordeaux por Simon Millanges, incluindo os livros I e II; a segunda, de 1582, também publicada em Bordeaux, com pequenas adições e alterações; a terceira, de 1587, publicada em Paris por Jean Richer; a quarta, de 1588, publicada em Paris por Abel L'Angelier, incluindo o livro III e adições aos livros I e II; e a quinta, de 1595, publicada três anos após a morte de Montaigne, também em Paris, com correções realizadas por Marie de Gournay, 'filha por aliança' do autor.” Cf. QUERUBINI, E. “Notas sobre a presente edição” In MONTAIGNE, M. Ensaios, p. 11.

2 Respectivamente os ensaios: XXIX. Da virtude, Livro II, p. 667-676; LV. Dos odores, p. 336-337 e; XXXI. Dos canibais, Livro I, p. 234-245 (MONTAIGNE, M. Ensaios). 
trata casualmente". ${ }^{3}$ Seja como for, para o crítico alemão, ainda hoje é difícil definir em que consiste sua obra e é quase incompreensível que os Ensaios tenham alcançado repercussão no momento histórico de sua publicação, principalmente se levarmos em conta que "toda realização necessita de um destinatário (...), de um público". 4 O público dos Ensaios ainda não existia e, contudo, dirigindo-se a uma coletividade não existente até aquele momento, é a partir de seu livro que ela cobra existência - e esse é um dos motivos pelos quais Auerbach afirmará que com Montaigne instituiu-se, pela primeira vez no Ocidente, a figura do leigo na condição de escritor. Ademais, como enuncia Eduardo Lourenço, com Montaigne institui-se também “a primeira figura moderna da singularidade" 5 e os Ensaios seriam, assim, o lugar onde, a partir da vida escrita, uma aventura análoga à de Colombo teria acontecido: “a da descoberta do Homem como a sua própria América". ${ }^{6}$ Não sendo o conhecimento a ferramenta capaz de se aproximar da singularidade desse homem, será a experiência o eixo norteador desse pensamento.

Em linhas gerais, podemos entender por conhecimento os saberes consolidados pela tradição (principalmente através das instituições à época de Montaigne: a Igreja e o Estado); já o campo da experiência diria respeito tanto aos acontecimentos de que Montaigne participou ou que ele testemunhou ao longo de sua vida quanto ao modo específico com que o autor dos Ensaios lida com a tradição de seu tempo. Partindo dessa premissa, o ensaio torna-se o gênero que, falando do mundo desde uma posição ordinária, cotidiana e sobretudo pessoal, trata de revelar a singularidade daquele que escreve. Isso faz com que, a partir do ensaio, seja possível universalizar a singularidade em vez de reduzir as especificidades numa ideia geral: através da exposição dos saberes relacionados aos objetos que o mundo oferece à apreensão, desdobra-se um saber mais especificamente sobre o modo como o indivíduo se relacionou com aquilo que estava diante de si. Cabe ressaltar ainda que, no interesse de Montaigne voltado para sua interioridade, há uma contrapartida que se desdobra num interesse contínuo e intenso pelo mundo exterior. Ou seja, a experiência aqui é o modo de acesso, ao mesmo tempo, da singularidade do homem e da singularidade de cada objeto no mundo, o

3 AUERBACH, E. “O escritor Montaigne”, p. 149.

4 AUERBACH, E. “O escritor Montaigne”, p. 149.

5 LOURENÇO, E. “Montaigne ou a vida escrita”, p. 535.

6 LOURENÇO, E. “Montaigne ou a vida escrita”, p. 536. 
que torna possível estabelecer outros modos e outras concepções do que seja pensar e conhecer. Além disso, não podemos desconsiderar a relação de Montaigne com o ceticismo pirrônico e a influência que este teve em seu pensamento quando consideramos o privilégio da experiência em detrimento do conhecimento no modo como nos Ensaios o pensamento é estruturado.

\subsection{ENSAIO: UM GÊNERO CÉTICO}

Richard Popkin, em sua História do ceticismo de Erasmo a Espinoza, afirma que o ceticismo, enquanto concepção filosófica organizada, teve sua origem na Grécia Antiga como uma reação às noções acerca da verdade e da forma de conhecimento da natureza no período grego clássico, noções consideradas por filósofos daquele momento como dogmáticas. Posteriormente, no período helenista, uma série de revisões sobre o problema do conhecimento foi desenvolvida, culminando, no que fiz respeito ao ceticismo, sinteticamente, em dois argumentos céticos: 1) "nenhuma forma de conhecimento é possível”; e 2) "não há evidência adequada ou suficiente para determinar qual forma de conhecimento é possível ou não, portanto, devemos suspender o juízo acerca de toda e qualquer questão relativa ao conhecimento". ${ }^{7}$ A primeira concepção resume o que se denomina ceticismo acadêmico; a segunda resume o ceticismo pirrônico.

O ceticismo acadêmico é assim chamado porque foi formulado na Academia de Platão por volta do século III a.C, com base em princípios socráticos sintetizados na famosa frase “Só sei que nada sei”. Entretanto, no que diz respeito à relação de Montaigne com o ceticismo - aquilo que aqui nos interessa -, nos deteremos na corrente pirrônica desta filosofia. Ao contrário dos acadêmicos, Pirro de Élis (c. 360 a 275 a.C) não era propriamente um teórico, mas uma espécie de exemplo encarnado e vivo da atitude cética. Seu interesse era evitar a infelicidade que poderia se originar a partir de qualquer teoria dos valores e, para isso, argumentava que era necessário suspender os juízos, sobretudo os éticos ou morais. Contudo, é atribuído a Enesidemo (c.100 a.C a 40 a.C.) a formulação teórica do pirronismo. Elaborando seus “Tropos”, espécie de reunião de procedimentos capazes de levar à suspensão do juízo em relação a várias questões, sobretudo àquelas onde houvesse "pretensões a conhecimentos que vão

7 POPKIN, R. História do ceticismo de Erasmo a Espinoza, p. 13. 
além das aparências." ${ }^{8}$ Alguns desses tropos sobreviveram a partir dos textos de Sexto Empírico (que viveu aproximadamente entre os séc. II e III d.C), e chegaram até nós com o nome de Hypotiposes pirrônicas.

Aparentemente, essas duas correntes céticas tiveram muito pouca influência na filosofia depois do helenismo. Particularmente a visão pirrônica ficaria quase desconhecida no Ocidente até a descoberta e tradução, no século XVI, dos manuscritos de Sexto Empírico, realizada por Henri Estienne e publicada em 1562. A tese defendida por Popkin é a de que o ceticismo, sobretudo sua vertente pirrônica, teve um papel especial na modernidade (e de modo distinto do que teve na antiguidade), particularmente no período que vai da Reforma (1517) até a formulação da teoria cartesiana (1637), visto que a crise intelectual instaurada a partir da Reforma coincidiu historicamente com a retomada do interesse pelos argumentos céticos (leia-se, pirrônicos) e sua aplicação às questões da época. ${ }^{9}$ Montaigne foi o intelectual que, para Popkin, mais utilizou e incorporou o ceticismo pirrônico para analisar os problemas de sua época. Para além do famoso ensaio "Apologia a Raymond Sebond”, ${ }^{10}$ no qual Montaigne expõe e realiza uma defesa do ceticismo pirrônico em detrimento do ceticismo acadêmico, interessa mais aqui perceber como ele parece incorporar à forma dos Ensaios - seu projeto de pensamento - a decisão cética da suspensão do juízo. Tendo em vista a pluralidade de formas do conhecimento e a consequente falibilidade de um critério geral que determine a validade de apenas um modo de se conhecer as coisas (e a si mesmo), o ensaio surgiria no século XVI como um gênero cuja vocação seria cética.

Adorno, no século XX, ao pensar o ensaio como forma, parece concordar com essa hipótese. Para ele, “o ensaio é tão cético (...) [que], sem apologia, ele leva em conta a objeção de que não é possível saber com certeza os sentidos que cada um encontrará sob os conceitos." ${ }^{11}$ Dito de outro modo, o que se explicita nesse trecho é a afirmação de uma indeterminação constitutiva tanto da linguagem quanto dos conceitos (as ferramentas que os filósofos formularam para "agarrar" e conhecer os objetos do mundo). O que o ensaio faz, diante do problema da arbitrariedade do conhecimento,

8 POPKIN, R. História do ceticismo de Erasmo a Espinoza, p. 15.

9 Cf. POPKIN, R. Op. cit. “O Ressurgimento do Ceticismo Grego no Século XVI”, p. 49-87.

10 MONTAIGNE, M. Ensaios, p. 443-59o. Livro II (12).

11 ADORNO, T. “O ensaio como forma” In Notas de Literatura I, p. 29. 
é precisamente não negar essa mesma arbitrariedade, esse índice de incerteza e de indeterminação que reside em qualquer relação de conhecimento. Com os Ensaios, Montaigne consegue, através de uma nova forma (e um novo gênero) traduzir para o campo da linguagem e do pensamento o modo como o mundo se apresentava e era experimentado historicamente: um modo fragmentário, com incertezas e crises que forçavam os poderes a se colocarem em suspenso. E é também pelo ensaio ser um género cético que "a descontinuidade [lhe] é essencial (...); seu assunto é sempre um conflito em suspenso". ${ }^{12}$

Contudo, há que se perguntar: por que será que para dar conta desse projeto de pensamento Montaigne, que teve uma educação erudita desde muito cedo, elege justamente uma palavra comum e popular (uma palavra bárbara para o pensamento, podemos dizer, pois francesa, não latina ou grega) e alheia aos gêneros filosóficos até então conhecidos (como as confissões, os tratados, os discursos, os diálogos e as cartas, por exemplo)?

Em 1985, na ocasião do Prêmio Europeu do Ensaio, o ensaísta vencedor Jean Starobinski, grande estudioso da obra montaigniana, intitulou seu discurso com uma questão que nos é cara: é possível definir o ensaio? Afirmando previamente que o ensaio não se submete a nenhuma regra, em sua tentativa de resposta Starobinski decide lançar um olhar retrospectivo e etimológico em direção à origem do próprio termo, reivindicando que sua história, em si mesma, encerra aspectos que não podem deixar de ser considerados, ao contrário, contribuem para a compreensão da diferença e novidade do gênero. Cito:

Essai [“ensaio”], conhecido em francês desde o século 12, provém do latim tardio exagium, "balança”; “ensaiar” deriva de exagiare, que significa "pesar”. Nas vizinhanças desse termo encontramos "exame": agulha, lingueta do fiel da balança e, consequentemente, pesagem, exame, controle. Mas outra acepção de “exame” aponta para o enxame de abelhas, a revoada de pássaros. A etimologia comum seria o verbo exigo, empurrar para fora, expulsar, depois exigir. ${ }^{13}$

“Quantas tentações se o sentido nuclear das palavras de hoje resultasse do que elas significaram num passado longínquo!” - É assim que o ensaísta suíço aponta para

12 ADORNO, T. “O ensaio como forma” In Notas de Literatura I, p. 35.

13 STAROBINSKY, J. “É possível definir o ensaio?”, p. 43-44. 
a eloquência de significados implícitos ao termo. Para ele, quando dizemos ensaio falamos, a uma só vez, “pesagem exigente”, “exame atento”, mas também o “enxame verbal" ${ }^{14}$, a prosa livre daquele que escreve e examina a si mesmo. Se ensaio é um outro modo de dizer "balança", o gênero pode ser compreendido pela chave relacional, que só se equilibra a partir de um outro (seja ele qual for: um outro texto, uma outra experiência, uma outra teoria, uma outra pessoa), ou seja, a referência no ensaio tende a ser alheia, a estar já dada e conformada no mundo. Balança é também o símbolo daquilo que se equilibra a partir da suspenção (ou da equivalência) dos pesos e juízos, símbolo cético escolhido por Montaigne, vale indicar, para o seu brasão. Além disso, não podemos esquecer outra acepção (mais comum) do termo: quando falamos ensaio dizemos também daquilo que ainda não está pronto, daquilo que está em processo de construção e, por isso mesmo, é parcial, provisório e preliminar. Relacionando a pluralidade de significados produzida por Starobinski com a obra montaigniana, talvez pudéssemos supor que o ato de nomear esses escritos como Ensaios explicita as intenções da própria obra. Ainda sobre o nome ensaio, Adorno também endossa o caráter tateante e provisório que o termo implica em alemão:

Como a maior parte das terminologias que sobrevivem historicamente, a palavra "tentativa" [Versuch], na qual o ideal utópico de acertar na mosca se mescla à consciência da própria falibilidade e transitoriedade também diz algo sobre a forma, e essa informação deve ser levada a sério justamente quando não é consequência de uma intenção programática, mas sim uma característica da intenção tateante. ${ }^{15}$

Podemos dizer que à época de Montaigne era comum nomear os textos com o gênero no qual se abordavam as questões. Nomear de um gênero que não existe, contudo, aponta para a diferença crítica - e, por que não, cética - que essa obra desejou ou instaurou. Ao mesmo tempo, é provável que essa denominação tenha muito que ver com um ethos renascentista e humanista que estimulou, concomitantemente, o resgate da tradição clássica que privilegia o homem, as artes e a ciência e, por outro lado, a coragem para distanciar-se da tradição escolástica. Seja como for, não é sem razão que João Barrento em O gênero intranquilo, ao pensar a "anatomia geral” do ensaio em contraposição ao tratado, afirma que, do ponto de vista da perspectiva filosófica, o

14 STAROBINSKY, J. “É possível definir o ensaio?”, p. 45.

15 ADORNO, T. “O ensaio como forma” In Notas de Literatura I, p. 35. 
ensaio pode ser considerado “cético”, “crítico” e “aberto” enquanto o tratado seria “convicto” e "autoritário" e “conservador”. ${ }^{16}$

Perguntas tais como “É possível definir os Ensaios?”, “Qual a sua matéria?” ou “O que o autor pretendia quando o escreveu?” podem ser encaradas a partir da nota de abertura do livro de Montaigne, intitulada “Ao leitor”. Mais do que introduzir a obra, a nota parece produzir as condições de possibilidade do próprio projeto dos Ensaios. Em cada ensaio dirigido à realidade externa ou à interioridade daquele que escreve, Montaigne experimenta, a cada vez, a promessa e a insuficiência de seu intelecto - eis o aspecto reflexivo instaurado pelo gênero que, “julgando" a atividade do pensamento e observando a capacidade do "julgador", como que "desperta" uma nova instância no indivíduo - a autorreflexão, o conhecimento de si -, isto é, a dobra crítica e reflexiva que o eu, ao mesmo tempo enquanto sujeito (mim mesmo) e objeto (o outro) pode produzir através da escrita (de si e do mundo, um atravessado pelo outro). Para André Scoralick, em sua apresentação à nova edição dos Ensaios disponível aos leitores brasileiros, ${ }^{17}$ neles importariam menos as diversas matérias tratadas ao longo dos três volumes da obra e mais o modo como, ao emitir juízos sobre essas mesmas matérias, o autor revelaria a si mesmo, espelhando-se no livro escrito. Será isso que, logo na abertura do livro, a nota endereçada aos possíveis leitores deixará entrever: como “condição da correspondência entre o discurso e aquele que o pronuncia”, a veracidade e a destinação privada da obra serão a "condição do autodesvelamento do autor em seu estado habitual, ordinário e simples”. ${ }^{18}$ Passemos, assim, à leitura da nota:

\section{Ao leitor}

Eis aqui, leitor, um livro de boa fé.

Adverte-o ele de início que só o escrevi para mim mesmo, e alguns íntimos, sem me preocupar com o interesse que poderia ter para ti, nem pensar na posteridade. Tão ambiciosos objetivos estão acima de minhas forças. Votei-o em particular a meus parentes e amigos, e isso a fim de que, quando eu não for mais deste mundo (o que em breve acontecerá), possam nele encontrar alguns tra-

16 BARRENTO, J. O gênero intranquilo: anatomia do ensaio e do fragmento, p. 40.

17 MONTAIGNE, M. Ensaios.

18 SCORALICK, A. “A experiência da condição humana: uma introdução aos Ensaios de Montaigne” In: MONTAIGNE, M. Ensaios, p. 25. 
ços de meu caráter e de minhas ideias e assim conservem mais inteiro e vivo o conhecimento que de mim tiveram. Se houvesse almejado os favores do mundo, ter-me-ia enfeitado e me apresentaria sob uma forma mais cuidada, de modo a produzir melhor seu efeito. Prefiro, porém, que me vejam na minha simplicidade natural, sem artifício de nenhuma espécie, porquanto é a mim mesmo que pinto. Vivos se exibirão meus defeitos e todos me verão na minha ingenuidade física e moral, pelo menos enquanto o permitir a conveniência. Se tivesse nascido entre essa gente de quem se diz viver ainda na doce liberdade das primitivas leis da natureza, asseguro-te que de bom grado me pintaria por inteiro nu.

Assim, leitor sou eu mesmo a matéria deste livro, o que será talvez razão suficiente para que não empregues teus lazeres em assunto tão fútil e de tão mínima importância.

E agora, que Deus o proteja. ${ }^{19}$

De Montaigne, $\mathrm{em} 1^{\circ}$ de março de $1580 .{ }^{20}$

Após a afirmação de que os Ensaios consistem numa obra de boa-fé, ou seja, numa obra que pretende ser sincera, Montaigne comunica ao leitor a finalidade de seu livro - mais especificamente, quais eram as suas intenções quando o escreveu e a quem ele estaria endereçado. Escrevendo-o apenas para si mesmo e para alguns íntimos, espécie de retrato de uma vida, a finalidade desses escritos seria apenas, a partir dos temas abordados, deixar rastros - traços - de seu caráter e de suas ideias para aqueles que ama. Contudo, talvez devêssemos olhar com mais atenção para a frase que inaugura a nota: “eis aqui, leitor, um livro de boa-fé”. Espécie de convicção do sujeito de agir com justiça e lealdade com relação a alguém ou a algum princípio, a boa-fé que o autor diz conter no livro, se lida na chave de uma intenção e não de uma realização, abre margens para outras possibilidades interpretativas. Por exemplo, no vocabulário jurídico, quando se diz "boa-fé”, alude-se ao “estado de consciência de quem crê, por erro ou equívoco, que age com correção (...), podendo ser levado a ter seus interesses prejudicados". ${ }^{21}$ Assim, esse estado diria respeito mais à pretensão do autor dos Ensaios, que ao livro mesmo, o qual pode ser lido contra ou a despeito dessas mesmas intenções, uma vez que é ela, a obra, o que resta à parte de seu autor. E essa é uma das

19 No texto original, em francês, lê-se "A Dieu donc".

20 MONTAIGNE, Ensaios., p. 39-40.

21 Dicionário Houaiss de Língua Portuguesa, 2009. 
razões, por exemplo, de os Ensaios fundarem um gênero em vez de serem um diário. Neles, se não é possível garantir a correspondência entre o que o autor diz sobre as coisas e as coisas mesmas, pode-se, no entanto, garantir a correspondência entre o que diz sobre as coisas e o conteúdo de seus pensamentos. Assim, ao mesmo tempo em que Montaigne afirma, de saída, que a matéria de seu livro é ele mesmo, podemos afirmar, lendo os Ensaios, que esse eu montaigniano que compõe a matéria-prima de seus escritos é uma experiência de fragmentação, de mistura, e não de identidade a si.

Se, como diz em sua nota “Ao leitor”, Montaigne escreve para poucos íntimos, mas ao mesmo tempo publica esse livro íntimo, talvez ele esteja convidando cada leitor que se dispõe a ler um ensaio a se colocar numa posição de intimidade e amizade com o texto, simulando a relação que não foi possível estabelecer em outro local senão mediada pela leitura. Além disso, quando diz que o livro foi escrito sem a preocupação com os interesses que o mesmo poderia ter para a posteridade, o que está sendo feito, na verdade, é uma defesa da atualidade como destino do ensaio enquanto gênero: ele deve ser encarado como obra contemporânea e imersa em seu próprio tempo histórico, a ser atualizada em relação ao tempo histórico de cada leitor que venha a ler este livro. Mostra disso é que é com empolgação e esperança que Montaigne é atravessado pela descoberta do Novo Mundo, que ele lê como possibilidade de liberdade, alegria e autenticidade - a novidade daquilo que é outro, diferente, e por isso mesmo, desconhecido e cheio de possibilidades e promessas.

Se é com a devida razão que dizemos ser unânime na teoria do ensaio recorrer a Montaigne e seus Ensaios como o momento inaugural do gênero, Adorno, para quem “o todo é o não verdadeiro” ${ }^{22}$, ao inserir-se numa narrativa “oficial” das teorias do ensaio, operará um desvio. Em “O ensaio como forma”, ao pensar a especificidade da forma do ensaio para a filosofia, sem deixar de reconhecê-lo, não serão suas as palavras para endossar o mito da origem - é através de uma citação a Georg Lukács, outro filósofo e teórico do ensaio e seu interlocutor mais imediato nesse texto, ou seja, indiretamente, que Montaigne é nomeado. Cito:

O grande Sieur de Montaigne talvez tenha sentido algo semelhante quando deu a seus escritos o admiravelmente belo e adequado título de Essais. Pois a modéstia simples dessa palavra é uma altiva cortesia. O ensaísta abandona suas

22 ADORNO, T. Minima Moralia: reflexões a partir da vida lesada, p. 46. 
próprias e orgulhosas esperanças, que tantas vezes o fizeram crer estar próximo de algo definitivo: afinal, ele nada tem a oferecer além de explicações de poemas dos outros ou, na melhor das hipóteses, de suas próprias ideias. Mas ele se conforma ironicamente a essa pequenez, à eterna pequenez da mais profunda obra do pensamento diante da vida, e ainda a sublinha com sua irônica modéstia. ${ }^{23}$

Será que é possível dizer que, com esse gesto, mesmo reconhecendo a importância de Montaigne como criador do gênero, Adorno enfatiza justamente a distância entre o ensaio tal como elaborado no século XVI pelo nobre francês e o ensaio pensado pelo judeu alemão pós-segunda guerra mundial? Separam Michel de Montaigne e Theodor Adorno quatro séculos e, através deles, quase toda a história do ensaio. Talvez não haja, de um para o outro, "evolução”, mas antes complementariedade. Se, no capítulo anterior, tratava-se de confrontar e assim opor o método cartesiano ao ensaio como forma de exposição do pensamento e elaboração do conhecimento especificamente filosófico, trata-se, agora, de abordar o ensaio enquanto gênero ele mesmo que irrompe como novidade na modernidade e pensar a sua singularidade mesma para, desde uma perspectiva histórica, conseguir estabelecer relações de proximidade e distância entre os usos do ensaio na história da filosofia.

Convenhamos que, quando se trata da questão da origem, ela só interessa se for pensada como um salto, não como uma continuidade. E quando, por exemplo, a origem diz respeito à morte?

\subsection{UM OUTRO MODO DE DIZER AMIGO}

Em agosto de 1563, aos 32 anos de idade, Étienne de La Boétie, humanista e filósofo francês autor do Tratado sobre a servidão voluntária, morre em decorrência de uma grave disenteria em uma cabana nos arredores de Bordeaux, sob os cuidados de seu tio, de sua mulher e de seu melhor amigo - Michel de Montaigne. A história dessa amizade é amplamente conhecida e tematizada na história da filosofia, sobretudo a partir dos escritos que o próprio Montaigne dedicou ao amigo: a carta que escrevera a seu pai

23 LUKÁCS, G. apud ADORNO, T. "O ensaio como forma” In Notas de Literatura I, p. 25. 
alguns anos após a morte de La Boétie e o ensaio "Da amizade", 24 espécie de homenagem e declaração de luto pelo amigo, são testemunhos emblemáticos dessa relação.

No ensaio “Da amizade”, Montaigne remonta à caracterização aristotélica do termo, como descrita no livro VIII de Ética a Nicômaco. Considerada pelo filósofo grego, além de uma virtude, algo sumamente necessário à vida, a amizade seria de importância basilar para a sociedade e para o homem. Princípio organizador tanto do indivíduo quanto das boas relações sociais, a amizade seria, desde a perspectiva aristotélica da Ética, mais necessária que a justiça - só há justiça onde a amizade falha. ${ }^{25}$ Dividindo as espécies de amizades em bom, agradável ou útil, simplificando muito a caracterização aristotélica, podemos dizer que os maus amigos serão aqueles que mantêm suas relações com vistas à utilidade e ao prazer - sentido acidental do termo - e os bons amigos serão aqueles que, sendo intrinsecamente bons enquanto indivíduos, fazem da amizade extensão de sua própria bondade - sentido absoluto do termo. ${ }^{26}$ Pela breve apresentação da amizade em Aristóteles, é possível dizer que ela não é entendida simplesmente como um sentimento, mas sim como uma disposição de caráter, ${ }^{27}$ ou seja, como uma ética.

Aderindo à caracterização aristotélica do termo e indo além, no ensaio supracitado, a amizade é descrita por Montaigne como um modo de se relacionar com o outro na forma de uma natural complementaridade - "igual e geral", “temperada e serena", “o calor da amizade estende-se por todo o nosso ser". ${ }^{28}$ Diferente e, de algum modo, superior a todas as outras formas de relação, a amizade perfeita envolveria igualdade, qualidade necessariamente impossível nas demais relações sociais. Por exemplo, nas relações entre pais e filhos o respeito dominaria; entre irmãos, não necessariamente há o compartilhamento de interesses; no casamento haveria, desde o começo, a restrição da liberdade, por um lado, e a duração indeterminada e imposta, por outro. Somente a amizade aconteceria como relação sem desigualdade, natural e verdadeira: encontro

24 MONTAIGNE, M. “Sobre algumas particularidades da doença e da morte de Étinne de La Boétie”, p. 225-239 e também MONTAIGNE, M. Ensaios, Livro I, 28.

25 ARISTÓTELES, Ética a Nicômaco, Livro VIII, p. 179 (1155a25).

26 ARISTÓTELES. Ética a Nicômaco, p. 183 (1157b).

27 ARISTÓTELES. Ética a Nicômaco, p. 183 (1157b30).

28 MONTAIGNE, M. "Da amizade” In: Ensaios, p. 217. 
de almas necessário e não contingente, ela é experimentada como a possibilidade de uma identidade sem falhas, como uma ontologia partilhada - ou melhor, partida.

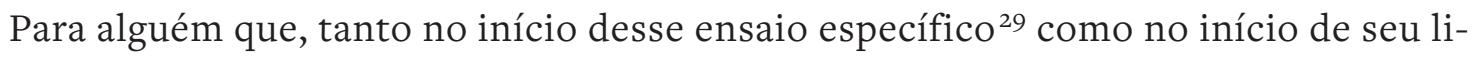
vro $^{30}$ adverte o leitor sobre a ingenuidade, circunstância e particularidade de seus escritos, é de se estranhar uma descrição tão absoluta sobre os tipos possíveis de relações humanas. Contudo, não devemos esquecer que a todo o tempo trata-se, no fundo, de encontrar formas de dizer a amizade a partir de uma experiência específica da mesma: aquela vivida e compartilhada entre La Boétie e Montaigne. Ou seja, fazendo dessa relação particular um paradigma de amizade, nesse ensaio, o valor absoluto do termo é erguido sob uma experiência singular, vivida e só depois narrada por aquele que escreve. Se, nesse ensaio, o absoluto funda-se num caso particular, isso faz com que a verdade passe a ter relação de fundamento não com o método da prova, mas sim com o testemunho de uma singularidade. É possível dizer que esse procedimento de fundamentação, sendo particular e não geral, não se restringe ao ensaio sobre a amizade especificamente, mas é ele mesmo o modo próprio de construção de cada texto dos Ensaios de Montaigne. Portanto, a atenção à particularidade do “absoluto” fundado cada vez a cada ensaio será uma das características do gênero na história da filosofia. Além disso, existe no ensaio uma espécie de chamado ao entendimento que não se dá por meio do conhecimento da cultura, mas sim por meio da experiência. Montaigne convoca àqueles - os leitores - que já tiveram algum dia uma experiência análoga a que ele testemunha ter vivido ("gostaria de me dirigir aqui somente a pessoas que tenham conhecido aquilo de que falo" ${ }^{31}$ ) para que, naquilo que também viveram, aprendam com a experiência escrita no ensaio. No fundo, parece haver uma espécie de impossibilidade de se saber o que é de fato a coisa vivida e escrita - nesse caso, a amizade - totalmente. E há. Ela é da ordem do dizível, claro, e da intelecção, também, mas há nela sempre algo de imponderável, de inominável, de intransferível, pois a experiência nunca se deixa mostrar por completo. Todavia, o que se aprende

29 "O mesmo ocorreu nesse livro, composto unicamente de assuntos estranhos, fora do que se vê comumente, formado de pedaços juntados sem caráter definido, sem ordem [e] sem lógica” Cf. MONTAIGNE, M. “Da amizade”, p. 215.

30 “Assim, leitor, sou eu mesmo a matéria deste livro" Cf. MONTAIGNE, M. “Ao leitor”. Ensaios, p. 40 31 MONTAigne, M. “Da amizade”. In: Ensaios, p. 224. 
mais radicalmente com Montaigne e seus Ensaios parece ser a possibilidade de haver (e, sobretudo, escrever desde ou sobre) experiências singulares.

Ademais, é curioso o modo como Montaigne inicia o ensaio “Da amizade": fazendo uma analogia entre seu livro e o procedimento de um pintor que, ao dar forma a sua obra, começa pelo tema central e, aos poucos, preenche os espaços vazios com ornamentos e arabescos cuja função seria apenas agradar pela variedade. Esse recurso é curioso sobretudo porque a analogia não se estabelece positivamente: se os Ensaios são uma espécie de pintura, não haveria nele, por sua vez, tema central, e o livro é constituído apenas por “assuntos estranhos”, "pedaços juntados sem caráter definido", "sem ordem”32 e lógica, que só por acaso estariam em relação de vizinhança uns com os outros. "Corpo de uma bela mulher com uma cauda de peixe”, 33 como Horário descreve no famoso prólogo de sua Arte poética o "vício" de composição recorrente a pintores e poetas que arriscariam a unidade e a coerência de suas obras, parece ser essa justamente a escolha da configuração dos Ensaios. Pois, a partir dessa configuração seria possível provocar um estranhamento tanto diante dos objetos do mundo quanto diante dos objetos do conhecimento. Essa espécie de desarmonia temática e de conteúdo ganharia posteriormente a devida unidade - seja pela forma, seja pelo sujeito que escreve.

Contudo, sabemos, é para falar de um outro desajuste que Montaigne escreve especificamente "Da amizade". Como vimos, é justamente nesse ensaio que Montaigne a descreve, por um lado, a partir da categorização aristotélica e, por outro, de uma experiência particular de amizade com La Boétie, nos seguintes termos: uma união sem reservas, na qual não há nenhum traço de sujeição nem de obrigação - uma relação na qual tudo procede da liberdade. Nessa relação, Montaigne teria encontrado “a possibilidade de comungar com o outro sem subterfúgios, precauções ou reservas, e de encontrar, em resposta, uma confiança igual à sua”. ${ }^{34}$ Entendendo a amizade como uma “absoluta convergência de pensamentos, um dom mútuo pelo qual as vontades

32 MONTAIGNE, M. "Da amizade" In: Ensaios, p. 215.

33 Idem. Como bem observa Edson Querubini, editor e revisor técnico desta edição, note-se que Montaigne equipara seus Ensaios ao grotesco e fantástico destas composições. É interessante pensar essa tomada de posição contra Horário e sua Arte poética considerando o papel central que a forma do ensaio terá na crítica de arte, em oposição às poéticas classicistas.

34 QUERUBINI, E. “Notas sobre a presente edição” In: MONTAIGNE, M. Ensaios, p. 15. 
livres mergulham e se perdem uma na outra sem divisão, nem sujeição" e fazendo de sua relação com La Boétie um paradigma de amizade, de perfeita relação com o outro, por meio dela ele descreverá a teleia philia, isto é, a "amizade acabada”, encerrada em si mesma: relação perfeitamente horizontal, livre e sem obrigações. Como o título denuncia, se se trata de falar da amizade, o desconcerto inerente a esse ensaio específico diz respeito a uma ausência: com a morte de La Boétie, o amigo, como é possível continuar alguma amizade?

A pergunta que aqui se faz é se, de algum modo, não é possível deslocar essa condição particular de ausência e sentimento de fragmentaridade e incompletude de uma relação específica abordada em um ensaio específico para o gênero do ensaio. E se, feito o deslocamento, não seria possível deslocar mais uma vez a questão e assim conseguir vislumbrar uma relação, pelo viés da amizade, entre ensaio e filosofia, lendo o gênero do ensaio como um modo próprio de a filosofia, espécie de amizade continuada e constante entre o desconhecido e os saberes diversos e distantes (no tempo, no espaço, nos livros, na história e na vida) acontecer.

Como sugere Starobinski em Montaigne em movimento, os Ensaios, que podem ser lidos na chave de um diálogo interior do autor consigo mesmo, de uma pintura de si, são também, em alguma medida, um modo de Montaigne lidar com e ao mesmo tempo continuar sua amizade após a morte do amigo. Scoralick, lendo Montaigne e o projeto dos Ensaios também a partir da questão da amizade, afirma que ela, "na medida em que coloca diante do sujeito uma alma idêntica a sua, é a condição do conhecimento de si”. ${ }^{35} \mathrm{Na}$ ausência do amigo, resta a Montaigne fazer de seu livro um substituto possível dessa amizade, contraponto especular pelo qual é possível escrever-se a si mesmo e sobre o mundo. Já o filósofo italiano Giorgio Agamben, na primeira década do século XXI, relembra e comenta a relação entre a filosofia e a amizade justamente através de um ensaio. ${ }^{36}$

35 QUERUBINI, E. “Notas sobre a presente edição” In: MONTAIGNE, M. Ensaios, p. 15.

36 Prix Européen de l'Essai Charles Veillon 2006, recebido pelo filósofo em 19 de fevereiro de 2017, em Lousanne. Nessa ocasião Agamben lê uma primeira versão do texto que viria a ser o ensaio comentado nesta dissertação. Cf. AGAMBEN, G. "O amigo" In: O que é o contemporâneo? e outros ensaios, p. 92. 
No ensaio “O amigo”, a partir dos livros oitavo e nono da Ética a Nicômaco, nos quais Aristóteles se dedica a expor seu tratado sobre a amizade, Agamben propõe uma leitura paralela desses mesmos livros. Tomando como pressuposto o conhecimento das teses aristotélicas mais consolidadas sobre o tema (aquelas, por exemplo, que Montaigne utiliza como base para seu ensaio), Agamben deseja sublinhar uma passagem do tratado que parece conter a base ontológica da teoria. Ressaltando o caráter não apenas político do termo, mas propriamente o seu valor ontológico, de acordo com essa dupla perspectiva, a amizade não estaria atrelada tão somente à intersubjetividade, não sendo, assim, apenas uma relação entre sujeitos - capazes de, pela boa convivência e pelo consentimento, delimitar uma identidade e fundar uma sociedade. Mais que isso, a amizade é entendida pelo filósofo italiano como uma "des-subjetivação no coração mesmo da sensação mais íntima de si”. ${ }^{37}$ Isto é, mais do que uma categoria para a qual se predicaria a qualidade de ser ou ter um amigo, a amizade se atém ao próprio fato da existência, assumindo, assim, um estatuto ontológico. Contudo, essa existência, ao com-sentir ${ }^{38}$ a existência de um outro - o amigo - conserva uma potência política, um desejo de produzir relações de comunidade. Agamben diz que "a amizade é a com-divisão que precede a toda divisão, porque aquilo que há para repartir é o próprio fato de existir, a própria vida. E é essa partilha sem objeto, esse com-sentir originário que constitui a política." 39 Posto que o amigo é um outro si e não um si mesmo (um heteros autos, ${ }^{40}$ na interpretação agambeniana) a amizade teria como princípio ontológico a partilha - e, por isso, seria uma ontologia partida. Assim, o estatuto político da amizade é um atributo que derivaria de sua qualidade ontológica: ontologicamente múltipla e não-idêntica, a amizade pressupõe abertura, demandando sempre a participação de um fora de si, de um outro que ao mesmo tempo esteja junto: de um outro que compartilhe.

Apresentada como uma "des-subjetivação de si", a amizade, ao ser a instância que nomeia essa ontologia partida e ao mesmo tempo partilhada do ser, ou seja, signo daquilo que é dividido e não-idêntico a si, o eu e o amigo são as duas faces, os dois

37 AGAMBEN, G. “O amigo” In: O que é o contemporâneo? e outros ensaios, p. 90.

38 Con-sentire em italiano, tradução do termo grego synaisthanesthai. Vinícius Honesko, tradutor da versão brasileira mantém a hifenização da palavra para marcar a leitura agambeniana.

39 AGAMBEN, G. “O amigo” In: O que é o contemporâneo? e outros ensaios, p. 92. 40 AGAMBEN, G. “O amigo” In: O que é o contemporâneo? e outros ensaios, p. 89. 
polos emblemáticos dessa condição humana. Como condição que se transforma em experiência de partilha que nos atravessa a todos, a amizade é, por fim, transposta por Agamben a uma questão de filosofia primeira, transformada, assim, em uma disposição epistemológica específica.

A amizade é tão estreitamente ligada à própria definição de filosofia que se pode dizer que sem ela a filosofia não seria possível. A intimidade entre amizade e filosofia é tão profunda que esta inclui o philos, o amigo, no seu próprio nome e, como frequentemente ocorre para toda proximidade excessiva, corre o risco de não conseguir realizar-se. No mundo clássico, essa promiscuidade e quase consubstancialidade do amigo e do filósofo era presumida, e é certamente por uma intenção de alguma maneira arcaizante que um filósofo contemporâneo - no momento de colocar a pergunta extrema: “O que é a filosofia?” - pode escrever que esta é uma questão para ser tratada entre amis. ${ }^{41}$

Se a filosofia é uma questão para ser tratada entre amigos e o ensaio pode ser lido como um outro modo de se dizer amigo, isto é, de continuar uma relação de amizade mesmo que o amigo real esteja ausente, ou seja, de continuar essa relação tanto pelo pensamento quanto pela linguagem, talvez seja possível dizer que, nesse sentido, o ensaio enquanto um gênero se apresente como um gênero radicalmente filosófico. De fato, na história da filosofia, essa relação parece ter caído em descrédito. Tornada um “partner incômodo", ${ }^{42}$ a amizade, contudo, não deixou de atuar, mesmo que clandestinamente. Mostra disso é que, desde o surgimento do gênero com Montaigne, o ensaio permaneceu resistindo enquanto uma forma, e filósofos não deixaram de utilizar ou se inspirar na forma montaigniana para, com ela ou a partir dela, continuar afirmando, mesmo que clandestinamente, o prazer da amizade.

\section{BIBLIOGRAFIA}

ADORNO, Theodor W. Minima moralia: reflexões a partir da vida lesada. Tradução: Gabriel Cohn. Rio de Janeiro: Azougue, 2008.

Notas de Literatura I. Tradução: Jorge de Almeida. São Paulo: Duas Cidades;

Ed. 34, 2003 .

41 AGAMBEN, G. "O amigo” In: O que é o contemporâneo? e outros ensaios, p. 79.

42 AGAMBEN, G. "O amigo" In: O que éo contemporâneo? e outros ensaios, p. 80. 
AGAMBEN, Giorgio. O que é o contemporâneo? e outros ensaios. Tradução: Vinícius Honesko. Chapecó: Ed. Argos, 2009.

ARISTÓTELES. Aristóteles. São Paulo: Abril Cultural, 1996. (Os Pensadores)

AUERBACH, Erich. “O escritor Montaigne”. In: Ensaios de literatura ocidental. São Paulo: Duas Cidades/Editora 34, 2007.

AZAR, Celso. "Método e estilo, subjetividade e conhecimento nos ensaios de Montaigne”. Revista Kriterion. Belo Horizonte, n. 126, Dez/2012, p. 559-578.

BARRENTO, João. O gênero intranquilo: anatomia do ensaio e do fragmento. Lisboa: Ed. Assírio \& Alvim, 2010.

LOURENÇO, Eduardo. "Montaigne ou a vida escrita”

MONTAIGNE, Michel. Ensaios. Tradução: Sérgio Millet (texto integral). São Paulo: Ed. $34,2016$.

“Sobre algumas particularidades da doença e da morte de Étinne de La Boétie”. Tradução: André Telles. Revista Serrote, n. 16. São Paulo: IMS, março de 2014. POPKIN, Richard. História do ceticismo de Erasmo a Espinoza. Tradução: Danilo Marcondes de Souza Filho. Rio de Janeiro: Francisco Alves, 2000.

SCHLEGEL, Friedrich. Conversa sobre a poesia e outros fragmentos. São Paulo: Iluminuras, 1994 .

SCORALICK, André. "A experiência da condição humana: uma introdução aos Ensaios de Montaigne” In Ensaios. Tradução: Sérgio Millet (texto integral). São Paulo: Ed. 34, 2016.

STAROBINSKY, Jean. “É possível definir o ensaio?”. Revista Serrote, n. 10. São Paulo: IMS, março de 2012.

QUERUBINI, E. “Notas sobre a presente edição” In Ensaios. Tradução: Sérgio Millet (texto integral). São Paulo: Ed. 34, 2016. 